\title{
PEMBERDAYAAN PEREMPUAN \\ MELALUI KEGIATAN EKONOMI KREATIF
}

\section{ABDURRAAFI' MAUDUDI DERMAWAN}

email:rafi.derma@gmail.com

Mahasiswa Pascasarjana Institut Teknologi Bandung

\begin{abstract}
The position and condition of women in Indonesia are considerably far from men, especially in some aspects of life as social, politics, economics, education, and culture. This phenomenon, furthermore, portrays that women is still in a marginal state. Therefore, there should be a special treatment to avoid such problems. The women themselves could gain a special care seriously. They could work on creative economy sectors, for instance because of 14 aspects of creative economy that will be introduced in this article.
\end{abstract}

Keywords: Condition, Developing, Women, Economy, Creative

\section{PENDAHULUAN}

Indonesia pada saat ini sedang menuju pada taraf kemajuan ekonomi yang cukup menggembirakan. Kemajuan ekonomi bisa dirasakan oleh masyarakat dalam segala sektor, baik sektor masyarakat desa, masyarakat kota, dalam dan luar negeri. Walaupun ada saat-saat tertentu, adakalanya perekonomian Indonesia mengalami penurunan, tetapi masyarakat Indonesia berusaha bangkit memperbaiki ekonominya, khususnya ekonomi keluarga. Namun kemajuan ekonomi belum dirasakan sepenuhnya oleh kaum perempuan. Perempuan masih sangat tergantung pada ekonomi suaminya, sehingga perempuan kurang mandiri dalam ekonominya. Disamping itu, sebaliknya perempuan juga terbatas dalam mengakseskan dirinya dalam bidang perekonomian. Hal ini disebabkan kaum perempuan banyak melakukan kegiatan-kegiatan domestik, sejak remaja maupun setelah menikah, sehingga waktu mereka untuk meningkatkan pengetahuan dan memberdayakan dirinya menjadi sangat terbatas. Kalau saja seandainya perempuan mendapat dukungan dari orangtua untuk memberikan kesempatan untuk memperoleh pendidikan yang layak padanya pasti sejak memasuki usia dewasapun, seorang perempuan akan mandiri merintis perekonomiannya.

Perempuan pedesaan pada umumnya banyak melakukan pekerjaan di ranah domestikdan publik, nmun perempuan pedesaan tetap terpinggirkan dalam menjangkau sumber daya. Sejak dilaksanakan pembangunan pertanian di Jawa tahun 1970 an banyak berdampak pada bergesernya tenaga kerja dari sektor pertanian. Perempuan Jawa merupakan kelomok tenaga kerja paling dirugikan oleh pembangunan di sektor pertanian. Perempuan mencari sumber pendapatan di luar pertanian dengan bekerja seadanya sebagai buruh dengan upah sangat rendah (Stoler, 1982; Sayogjo, 1984) Kemiskinan di lereng Gunung Merapi terkait dengan belum dilibatkannya perempuan secara komprehensif dalam pemanfaatan sumber daya yang tersedia di wilayah. ${ }^{70}$

${ }^{70}$ Hastuti dan Dyah Respati. Model Pemberdayaan Perempuan Miskin Berbasis Pemanfaatan Sumber Daya Perdesaan Upaya Pengentasan Kemiskinan Di Pedesaan: Studi di LerengMerapi Daerah Istimewa Yoyakarta, (Fakultas Ilmu Sosial Ekonomi UNY Yogyakarta), hlm.2. 
Hal inipun juga telah dijelaskan oleh Dreze and Sen $^{71}$ bahwa kondisi dan posisi perempuan di Indonesia masih jauh tertinggal dibandingkan dengan laki-laki dalam berbagai aspek kehidupan, antara lain di bidang sosial, politik, ekonomi, pendidikan dan budaya. Fenomena ini menunjukkan perempuan masih menjadi kaum yang termajinalkan sehingga persoalan pemberdayaan perempuan memiliki bidang garapan yang luas. Salah satu bidang yang menarik untuk dibahas adalah pemberdayaan ekonomi bagi perempuan. Keberdayaan perempuan dibidang ekonomi adalah salah satu indikator meningkatnya kesejahteraan. Saat perempuan menjadi kaum terdidik, mempunyai hakhak kepemilikandan bebas untuk bekerja di luar rumah serta mempunyai pendapatan mandiri, inilah tanda kesejahteraan rumah tangga meningkat.

Padahal kenyataannya apabila perekonomian perempuan maju, baik dari skala keluargamaka akan mendorong pertumbuhan dan peningkatan perempuan dalam skala global. Kemiskinan perempuan telah ikut menyumbang keterpurukan pembangunan. Menurut data PBB, $1 / 3$ dari penduduk dunia hidup dibawah garis kemiskinan, sementara itu sekitar $70 \%$ dari mereka adalah perempuan. Karenanya perlu dilakukan cara tepat guna mengentaskan kemiskinan yang dialami perempuan. Di Indonesia ada berbagai dimensi yang menimpa perempuan: akibat posisi tawar yang lemah dalam masyarakat, kultur yang represif, miskin akibat bencana dan konflik, diskriminasi di ruang publik dan domestik, serta tidak pedulinya negara dalam mengeluarkan kebijakankebijakan yang bermanfaat guna menentaskan perempuan dalam kemiskinan. Dalam kenyataannya banyak praktek diskriminasi dilakukan terhadap perempuan. ${ }^{72}$

Data yang dihimpun oleh PBB bahwa $1 / 3$ penduduk duniahidup dalam kemiskinan dan 70\%nya adalah perempuan merupakan angka yang fantastik dan tidak dapat diabaikan. Persoalan kemiskinan perempuan merupakan hal yang serius perlu mendapat perhatian dan penanganan yang optimal. Pemerintah dan masyarakat melalui partisipasi aktif, harus dapat melakukan upaya untuk memberdayakan peran perempuan, utamanya dalam bidang ekonomi, sehingga diharapkan kemiskinan perempuan dapat berkurang bahkan perempuan dapat berdiri sejajar dengan laki-laki dalam kemandirian ekonomi.

Berdasarkan data-data di atas jelas bahwa pada garis besar, perempuan Indonesia hidup dalam kemiskinan. Sebagaimana fakta di atas, kemiskinan perempuan disebabkan karena sempitnya akses yang memberikan kesempatan bagiperempuan yangmandiri secara ekonomi, ketergantungan pada ekonomi suaminya, dan terbatasnya kesempatan dan waktu yang dapat mendukung bagi perempuan untuk maju.

Kemiskinan menurut penyebabnya terbagi 2 macam. Pertama adalah kemiskinan kultural kemiskinan yang disebabkan oleh adanya faktor-faktor adat atau budaya suatu daerah tertentu yang membelenggu seeorang atau sekelompok masyarakat tertentu sehingga membuatnya tetap melekat dengan kemiskinan. Kemiskinan seperti ini bisa dihilangkan atau sedikitnya bisa dikurangi dengan mengabaikan faktorfaktoryang menghalangi untuk melakukan perubahanke arah tingkat kehidupan yang

71 Retni Endah Supeni dan Maheni Ika Sari, Upaya Pemberdayaan Ekonomi Perempuan Melalui Pengembangan Manajemen Usaha KecilStudi diskriptif pada Kegiatan Usaha Kecil Ibu-ibu Desa Wirolegi Kabupaten Jember, Dampingan Pusat Studi Wanita UM Jember.Seminar Nasional Ilmu Ekonomi Terapan Fakultas Ekonomi UNIMUS, (Universitas Muhammadiyah Jember. 2011), hlm. 101.

${ }^{72}$ Ibid., hlm. 103 
lebih baik. Kedua, adalah kemiskinan struktural, yaitu kemiskinan yang terjadi sebagai akibat ketidakberdayaan seseorang atau sekelompok masyarakat tertentu terhadap sistem atau tatanan sosial yang tidak adil karenanya mereka berada pada posisi tawar yang sangat lemah dan tidak memiliki akses untuk mengembangkan atau membedakan diri mereka sendiri dari perangkap kemiskinan atau dengan perkataan lain "seseorang atau sekelompok masyarakat menjadi miskin atau karena mereka miskin. "Penyebab kemiskinan tersebut juga tergantung dari bentuk kemiskinan yang dialami perempuan. Kemiskinan perempuan terjadi berakar pada tindakan ketidakadilan atau diskriminatif dalam mengakses sumber daya, baik ekonomi maupun dalam bentuk lainnya. Kemiskinan perempuan juga disebabkan secara struktural yang langgeng dalam budaya yang mengekang perempuan dan keputusan politik yang tidak memihak kepada perempuan. Jadi bila kita memahami persoalan kemiskinan, maka kita akan bisa memahami persoalan kemiskinan yang dialami perempuan dan menemukan akar kemiskinan perempuan. Dengan menemukan akar kemiskinan itu, akan menolong perempuan untuk keluar dari kemiskinan yang salah satunya dengan meningkatkan keberdayaan perempuan dibidang ekonomi sebagai salah satu indikator meningkatnya kesejahteraan, karena itu penguatan dan optimalisasi perempuan secara berkesinambungan dalam kehidupan ekonomi merupakan hal yang sangat penting. Kualitas kehidupan perempuan yang kurang menggembirakan merupakan akibat dari pendekatan pembangunan yang belum mengindahkan kesetaraan dan keadilan gender. Ini semua berawal dari diskriminasi terhadap perempuan yang menyebabkan perempuan tidak memiliki akses, kesempatan, dan kontrol atas pembangunan serta tidak memperoleh manfaat pembangunan yang adil dan setara dengan laki-laki. ${ }^{73}$

Sumber masalah kemiskinan yang dihadapi oleh perempuan menurut Muhadjir dalam Ni Luh Arjani (2007) terletak pada budaya patriarki yaitu nilai-nilai yang hidup dimasyarakat yang memposisikan laki-laki sebagai superior dan perempuan sebagai subordinat. Budaya patriarki ini tercermin dalam kehidupan berkeluarga, bermasyarakat, berbangsa dan bernegara dan menjadi sumber pembenaran terhadap sistem distribusi kewenangan, sistem pengambilan keputusan, sistem pembagian kerja, sistem kepemilikan, dan sistem distribusi resoursis yang bias gender. Kultur yang demikian ini akhirnya akan bermuara pada terjadinya perlakuan diskriminasi, marginalisasi, eksploitasi maupun kekerasan terhadap perempuan. ${ }^{74}$

Budaya patriarki yang sudah ada sejak zaman nenek moyang Indonesia telah memposisikan perempuan sebagai manusia yang miskin, baik miskin secara kultural maupun struktural. Tradisi patriarki menyebabkan perempuan Indonesia pada umumnya kurang dan bahkan tidak mempunyai peluang untuk mengakseskan dirinya pada hal-hal yang dapat meningkatkan kompetensi di berbagai sektor, khususnya perekonomiandan memajukan dirinya setara dengan laki-laki. Pada kehidupan keluarga, posisi anak perempuan tidak mendapat tempat yang sama dengan anak laki-laki. Anak perempuan tidak memiliki kebebasan sebagaimana anak laki-laki. Anak perempuan desa tidak memiliki kesempatan untuk memperoleh pendidikan yang sama dengan anak lakilaki. Anak perempuan biasanya memperoleh pendidikan hanya sampai pada tingkat

\footnotetext{
${ }^{73}$ Ibid, hlm. 103

${ }^{74}$ Ibid, hlm. 104
} 
SLTA. Setelah menamatkan pendidikannya di SMA, biasanya anak perempuan dinikahkan oleh orangtuanya. Setelah dinikahkan, anak perempuan akan mempunyai anak, melayani suami dan mengurus pekerjaan rumah lainnya. Bisa dibayangkan perempuan akan terjebak pada rutinitas domestik, sehingga tidak mempunyai waktu untuk menambah pengetahuan, keterampilan, dan meningkatkan kualitas dirinya dan keluarganya.

Dengan demikian, upaya pemberdayaan perempuan melalui berbagai kegiatan ekonomikreatif sangat diperlukan untuk meningkatkan kualitas diri dan kehidupan perempuan dan keluarga. Apalagi gerak dinamika pembangunan pada era globalisasi menuntut peningkatan sumber daya manusia, baik secara kualitas maupun kuantitas. Pengembangan ekonomi kreatif tidak akan berkembang jika sebagian dari jumlah penduduk Indonesia, yaitu perempuan tidak berpartisipasi dan ikut serta aktifdalam pembangunan ekonomi kreatif tersebut. Sebagian jumlah penduduk di Indonesia adalah perempuan, jika perempuan tidak memiliki pengetahuan dan keterampilan dibidang ekonomi kreatif, maka bisa dipastikan Indonesia akan terus mengimpor dan tergantung pada produk-produk luar negeri,bisa dipastikan Indonesia tidak akan mandiri, dan akan terus menjadi pembeli, sehingga keuangan masyarakat Indonesia akan terkuras untuk memenuhi berbagaikebutuhanyang notabene diproduksi dari luar negeri. Contoh yang sangat signifikan adalah ketergantungan Indonesia pada produk-produk negara tirai bambu.

Produk impor dari negeri Tirai Bambu tercatat menguasai pasar terbesar hampir disemua jenis produk. Kecuali produk makanan dan minuman yang importnya dikuasai Malaysia. Produk Cina menguasai pangsa impor terbesar untuk produk elektronika, pakaian jadi, alas kaki, dan mainan anak-anak. Dari total impor produk elektronika sebesar US\$2,45 miliar, produk elektronika dari Cina menguasai 33,3\% atau senilai US $\$ 817,9$ juta. Untuk pakaian jadi, produk Cina menguasai pasar hingga 31,9\% dari total nilai impor pakaian jadi US $\$ 109,4$ juta. ${ }^{75}$

Bila diperhatikan data di atas, sesungguhnya Indonesia sangat tergantung pada produk-produk impor dari Cina. Bila produk-produk tersebut diproduksi oleh perempuan-perempuan Indonesia, maka hal ini tentu saja akan mempunyai pengaruh positif yang sangat signifikan, baik bagi kemajuan dan peningkatan perekonomian Indonesia pada umumnya, peningkatan kualitas perempuan, memajukan perekonomian dan kesejahteraan perempuan dan keluarganya.

Era globalisasi dan konektivitas mengubah cara bertukar informasi, berdagang, dan konsumsi dari produk-produk budaya dan teknologi dari berbagai tempat di dunia. Dunia menjadi tempat yang sangat dinamis dan kompleks sehingga kreativitas dan pengetahuan menjadi suatu aset yang tak ternilai dalam kompetisi dan pengembangan ekonomi. Ekonomi kreatif adalah sebuah konsep yang menempatkan kreativitas dan pengetahuan sebagai aset utama dalam menggerakkan ekonomi.Konsep ini telah memicu ketertarikan berbagai negara untuk melakukan kajian seputar ekonomi kreatif dan menjadikan ekonomi kreatif sebagai model utama pengembangan ekonomi. ${ }^{76}$ Konsep ekonomi kreatif tidak akan teraplikasi dan berkembang jika tidak didukung

\footnotetext{
${ }^{75}$ Sukmika Mardalena, Dominasi Produk Cina di Indonesia,Makalah,(Universitas Riau. Fakultas Ilmu Sosial dan Ilmu Politik, ProdiHubungan Internasional, 2012.).

${ }^{76}$ Indonesia Kreatif, 2013. Creatif Economy. (Online)
} 
dengan sumber daya yang mempunyai kompetensi yang memadai, oleh sebab itu, pelatihan dan pemberdayaan perempuan sebagai sumber daya yang jumlahnya sangat besar di Indonesia sangat urgen untuk menjadi perhatian serius, baik dari kalangan pemerintah maupun masyarakat pada umumnya.

\section{PEMBERDAYAAN EKONOMI PEREMPUAN}

Istilah pemberdayaan (empowerment), menurut Ginanjar Kartasasmita adalah upaya untuk membangun daya (masyarakat) dengan mendorong, memotivasi, dan membangkitkan kesadaran akan potensi serta berupaya untuk mengembangkan. ${ }^{77}$

Pemberdayaan adalah sebuah proses dimana orang menjadi cukup kuat untuk berpartisipasi dalam berbagai pengontrolan atas, dan mempengaruhi terhadap kejadiankejadian serta lembaga-lembaga yang mempengaruhi kehidupannya. Pemberdayaan didefinisikan sebagai proses dimana pihak yang tidak berdaya bisa mendapat kontrol yang lebih banyak terhadap kondisi atau keadaan dalam kehidupannya. Kontrol ini meliputi kontrol terhadap berbagai sumber (mencakup fisik dan intelektual) dan ideologi meliputi (keyakinan, nilai, dan pemikiran) ${ }^{78}$

Pemberdayaan merupakan transformasi hubungan kekuasaan antara laki-laki dan perempuan pada empat level yang berbeda, yakni keluarga, masyarakat, pasar, dan negara. Konsep pemberdayaan dapat dipahami dalam dua konteks. Pertama, kekuasaan dalam proses pembuatan keputusan dengan titik tekan pada pentingnya peran perempuan. Kedua, pemberdayaan dalam term yang berkaitan dengan fokus pada hubungan antara pemberdayaan perempuan dan akibatnya pada laki-laki di masyarakat yang beragam. ${ }^{79}$

Dengan demikian pengertian pemberdayaan adalah upaya memberikan kesadaran tentang potensi dalam diri seseorang yang dapat berdaya guna dan memberikan keuntungan bagi dirinya maupun orang lain, memberikan motivasi agar tumbuh semangat untuk mengaktifkan potensi yang dimiliki, dan mengembangkannya melalui berbagai pembelajaran dan pelatihan, sehingga diperoleh pengetahuan dan keterampilan serta diaplikasikan dalam kegiatan kongkrit yang menguntungkan.

Sosok perempuan menurut tradisi hingga dewasa ini utamanya di daerah pedesaan, selalu dianggap sebagai sosok kanca wingking, yang selalu berurusan dengan dapur, kasur, dan sumur. Aktivitas domestik yang tidak berhenti sampai anak dan suami tertidur, telah menguras waktu perempuan untuk meningkatkan potensi dankompetensi yang ada di dalam dirinya, ditambah lagi sosok perempuan tidak diberi kesempatan oleh orang tuanya sejak kecil untuk memperoleh pendidikan yang dapat memberikan masa depan yang baik bagi anak perempuan, kondisi ini telah memiskinkan perempuan dalam berbagai sektor. Oleh sebab itu, konsep pemberdayaan sangat penting dan utama dilakukan bagi perempuan, sehingga perempuan memiliki kemandirian, baik secara ekonomi maupun secara mental.

${ }^{77}$ Merla Liana Herawati, Pemberdayaan Ekonomi Masyarakat Melalui Kerajinan Tempurung Kelapa: Studi Di DusunSantan Guwosari Pajangan Bantul, (Fakkultas Dakwah Dan Komunikasi. UIN Sunan Kalijaga Yogyakarta. 2014), (Skripsi).hlm. 28

${ }^{78}$ Edi Suharto, Pembangunan Kebijakan dan Kesejahteraan Sosial, (Bandung: Mizan. 2003), hlm. 35.

${ }^{79}$ Zakiyah, Pemberdayaan Perempuan oleh Lajnah Wanita,(Jurnal Pengkajian Masalah Sosial Keagamaan, XVII, Januari-Juni 2010), hlm. 44. 
Terdapat dua ciri dari pemberdayaan perempuan, yaitu pertama, sebagai refleksi kepentingan emansipatoris yang mendorong masyarakat berpartisipasi secara kolektif dalam pembangunan. Kedua sebagai proses pelibatan diri individu atau masyarakat dalam proses pencerahan, penyadaran, dan pengorganisasian kolektif sehingga mereka dapat berpartisipasi. ${ }^{80}$

\section{UNSUR-UNSUR DAN METODE PEMBERDAYAAN PEREMPUAN}

Menurut Kabeer (2001) dalam Mayoux (2005) ${ }^{81}$ menyatakan bahwa terdapat lima unsur utama yang perlu diperhatikan dalam proses pemberdayaan perempuan, yaitu sebagai berikut :

1. Welfare (Kesejahteraan). Aspek ini dapat dikatakan sebagai salah satu aspek yang penting dalam upaya peningkatan pemberdayaan perempuan. Tidak dapat dipungkiri bahwa dalam akses terhadap kesejahteraan, perempuan menempati posisi yang tidak menguntungkan. Menurut Claros and Zahidi ${ }^{82}$ Kesejahteraan ini dibagi ke dalam tiga unsur, yaitu pertama Partisipasi ekonomi perempuan merupakan hal yang penting yang tidak hanya mengurangi level kemiskinan pada perempuan melainkan sebagai langkah penting untuk meningkatkan pendapatan rumah tangga dan mendorong pembangunan ekonomi negara secara keseluruhan. Kedua, pencapaian pendidikan merupakan aspek yang fundamental dalam kegiatan pemberdayaan perempuan, dapat memperoleh pendidikan yang memadai, perempuan tidak akan mampu mengakses pekerjaan sektor formal, mendapatkan upah yang lebih baik, berpartisipasi dalam pemerintahan, dan mencapai pengaruh politik. Ketiga, Kesehatan dan kesejahteraan merupakan sebuah konsep yang terkait dengan perbedaan subtansial antara perempuan dan laki-laki dalam mengakses nutrisi yang cukup, kesehatan, fasilitas reproduksi dan mengemukakan keselamatan fundamental dan integritas seseorang. Amartya Sen (dalam Claros and Zahidi) ${ }^{83}$ menyatakan bahwa pendidikan, pekerjaan, dan kepemilikan hak perempuan memberikan pengaruh yang kuat untuk meningkatkan kemampuan mereka dalam menguasai lingkungan mereka dan memberikan kontribusi dalam pembangunan ekonomi. Partisipasi ekonomi tidak hanya berhenti pada meningkatkan jumlah perempuan bekerja, melainkan pada kesetaraan dalam pemberian upah.

2. Acces (Akses). Akses diartikan sebagai kemampuan perempuan untuk dapat memperoleh hak.akses terhadap sumber daya produktif seperti tanah, kredit, pelatihan, fasilitas, pemasaran, tenaga kerja, dan semua pelayanan publik yang setara dengan laki-laki. Akses terhadap teknologi dan informasi juga merupakan aspek penting lainnya. Melalui teknologi dan informasi, perempuan dapat meningkatkan produktivitas ekonomi dan sosial mereka dan mempengaruhi lingkungan tempat mereka tinggal. Tanpa akses, pemahaman, serta kemampuan untuk menggunakan

\footnotetext{
${ }^{80}$ Zakiyah, Op. Cit. h. 44

${ }^{81}$ Retno Endah Supenidan Maheni Ika Sari. Upaya Pemberdayaan Ekonomi Perempuan Melalui Pengembangan Manajemen Usaha Kecil: Studi Diskriptif Pada Kegiatan Usaha Kecil Ibu-ibu Desa Wirolegi Kabupaten Jember, Dampingan Pusat Studi Wanita UM Jember. (Seminar Nasional Ilmu Ekonomi Terapan Fakultas Ekonomi UNIMUS.2011),hlm. 105

${ }^{82}$ Ibid, hlm. 105

${ }^{83}$ Ibid, hlm. 105
} 
teknologi informasi, perempuan miskin jauh lebih termajinalisasi dari komunitasnya, negaranya, dan bahkan dunia.

3. Consientisation (konsientisasi) Pemahaman atas perbedaan peran jenis kelamin dan peran gender.

4. Participation (partisipasi). Kesetaraan partisipasi perempuan dalam proses pembuatan keputusan, pembuatan kebijakan, perencanaan, dan administrasi. Partisipasi ini merujuk pada keterwakilan perempuan yang setara dalam struktur pembuatan keputusan baik secaara formal maupun informal, dan suara mereka dalam penformulasian kebijakan mempengaruhi masyarakat mereka.

5. Equality of Control (Kesetaraan Dalam Kekuasaan). Kesetaraan dalam kekuasaan dalam kekuasaan atas faktor produksi dan distribusi keuntungan sehingga baik perempuan maupun laki-laki berada dalam posisi yang dominan.

Welfare (Kesejahteraan), Acces (Akses), Consientisation (konsientisasi), Participation (partisipasi).Dan Equality of Control (Kesetaraan Dalam Kekuasaan) merupan unsurunsur dari pemberdayaan perempuan yang tidak hanya merupakan wacana atau konsep, namun harus diaplikasikan dengan baik dan benar, sehingga diharapkan perempuan dapat memajukan dan meningkatkan kualitas dan kesehteraan dirinya.

Metode dalam pemberdayaan perempuan, sebagai berikut :

1. Membongkar mitos kaum perempuan sebagai pelengkap dalam rumah tangga. Sebagaimana tradisi menganggap perempuan sebagai konco wingking (teman di belakang) bagi suami serta anggapan "swarga nunut neraka katul" (ke surga ikut ke neraka terbawa). Kata nunut dan katut dalam bahasa Jawa berkonotasi pasif dan tidak memiliki inisiatif, sehingga nasibnya sangat tergantung pada suami.

2. Memberi beragam keterampilan bagi kaum perempuan. Sehingga kaum perempuan juga dapat produktif dan tidak menggantungkan nasibnya kepada kaum laki-laki.

3. Memberikan kesempatan seluas-luasnya terhadap kaum perempuan untuk menempuh pendidikan dan mengaplikasikan pendidikannya dalam kegiatan pemberdayaan. ${ }^{84}$

Membongkar mitos kaum, Memberi beragam keterampilan, Memberikan kesempatan seluas-luasnya bagi perempuan untuk maju dan meningkatkandalam berbagai sektor pekerjaan, baik bidang pendidikan, kesehatan, ekonomi, sosial, politik, hankam, dan budaya. Semua ini merupakan kunci atau metode dalam upaya pemberdayaan perempuan dalam segala sektor.

\section{EKONOMI KREATIF}

Ekonomi kreatif merupakan aktifitas perekonomian yang lebih mengandalkan ide atau gagasan (kreatif) untuk mengelola material yang bersumber dari lingkungan di sekitarnya menjadi bernilai tambah ekonomi. ${ }^{85}$ Ekonomi kreatif menurut UNCTAD (2008:3)adalah sebagai berikut :

"Creativy in this contect refers to the formulation of new ideas and to the application of these ideas to produce original works of art and cultural products, functional creation, observable in

${ }^{84}$ Ismah Salman, Keluarga Sakinah Dalam Aisyiyah, (Jakarta: PSAP Muhammadiyah, 2005), hlm. 181

${ }^{85}$ Herie Saksono, Ekonomi Kreatif : Talenta Baru Pemicu Daya Saing Daerah, (Puslitbang Pemerintahan Umum dan Kependudukan Balitbang (BPP) Kementerian Dalam Negeri, 2012), hlm. 95. 
theway it contributes to entreupreneurship, forters innovation, enchaces productivity and promotes economic growth" 86

Creativy dalam kontek ini mengacu pada rumusan ide-ide baru dan untuk penerapan ide-ide untuk menghasilkan karya seni asli dan budaya produk, penciptaan fungsional, diamati dengan cara memberikan kontribusi untuk berwiraswasta,inovasi, produktivitas dan meningkatkan pertumbuhan ekonomi.

Di Indonesia Pemerintah sendiri melalui Departemen Perdagangan ${ }^{87}$ telah mengidentifikasi lingkup industri kreatif mencakup 14 subsektor, antara lain:

1. Periklanan (advertising): kegiatan kreatif yang berkaitan dengan jasa periklanan, yakni komunikasi satu arah dengan menggunakan medium tertentu. Meliputi proses kreasi, operasi, dan distribusi dari periklanan yang dihasilkan, misalnya riset pasar, perencanaan komunikasi periklanan, media periklanan luar ruang, produksi material periklanan, promosi dan kampanye relasi publik. Selain itu, tampilan periklanan di media cetak (surat kabar dan majalah) dan elektronik (televisi dan radio), pemasangan berbagai poster dan gambar, penyebaran selebaran, pamflet, edaran, brosur, dan media reklame sejenis lainnya, distribusi dan delivery advertisingmaterials or samples, serta penyewaan kolom untuk untuk iklan.

2. Arsitektur: kegiatan kreatif yang berkaitan dengan desain bangunan secara menyeluruh, baik dari level makro (town planning, urban design, landscape arcbitecture) sampai level mikro (detail konstruksi). Misalnya arsitektur taman, perencanaan kota, perencanaan biaya konstruksi, konservasi bangunan warisan sejarah, pengawasan konstruksi, perencanaan kota, konsultasi kegiatan teknik dan rekayasa seperti bangunan sipil d an rekayasa mekanika dan eletrikal.

3. Pasar Barang Seni: kegiatan kreatif yang berkaitan dengan perdagangan barangbarang asli, unik dan langka serta memiliki nilai estetika seni dan sejarah yang tinggi melalui lelang, galeri, toko, pasar swalayan dan internet, meliputi barang-barang musik, percetakan, automobile, dan film.

4. Lapangan usaha yang merupakan bagian dari kelompok industri Pasar Seni dan barang antikyaitu: a) Perdagangan besar barang-barang antic, b) perdagangan eceran barang antic yang mencakup mencakup usaha perdagangan eceran barang-barang antic, c) perdagangan eceran kaki lima barang antic, d) Jasa galeri dan rumah lelang untuk barang seni dan barang antic, baik yang dilakukan olehpemerintah maupun pihak swasta, e) kerajinan (craft): kegiatan kreatif yang berkaitan dengan kreasi, produksi dan distribusi produk yang dibuat atau dihasilkan oleh tenaga pengrajin yang berawal dari desain awal sampai proses penyelesaian produknya. Antara lain meliputi barang kerajinan yang terbuat dari batu berharga, serat alam maupun buatan, kulit, rotan, bamboo, kayu, logam (emas, perak, tembaga, perunggu dan besi), kaca, porselen, kain, marmer, tanah liat, dan kapur. Produk kerajinan pada umumnya hanya diproduksi dalam jumlah yang relative kecil (bukan produksi manusia). Sedangka lapangan usaha yang merupakan bagian dari kelompok industri kerajinan yaitu: (1) industri batik, (2) industri permadani, (3) industri

${ }^{86}$ NationsUNCTAD, Summary Creative EconomicReport, (USA: United, 2008).

${ }^{87}$ Dania Eka Putri dan Dwi Rizki Wijayanti. Perkembangan Ekonomi Kreatif Dalam Arus Perkembangan Ekonomi Modern, (Fakultas Pendidikan dan Ekonomi UPI Bandung. 2013). Skripsi, hlm. 11-35. 
bordir/sulaman, (4) industri kain rajut, (5) industri barang dari kulit dan kulit Buatan, (6) industri Anyam-anyaman dari Rotan dan Bambu, (7) industri anyamanyaman dari tanaman, (8) industri kerajinan ukir-ukiran dari kayu. (9) industri Alatalat dapur dari kayu, rotan dan bambu, dan (10) industri barang dari kayu, rotan, gabus. (11) industri perlengkapan dan peralatan rumah tangga dari Gelas rumah tangga, (12) industri barang-barang lainnya dari gelas, (13) industri perlengkapan rumah tangga dari porselin, (14) industri barang-barang dari tanah liat, (15) industri bahan bangunan dari tanah liat/keramik selain batu bata dan genteng, (16) industri barang dari marmer dan granit untuk keperluan rumah tangga dan pajangan, industri barang dari batu untuk keperluan rumah tangga dan pajangan, (17) jasa industri untuk bahan berbagai pekerjaan khusu terhadap logam dan barang-barang dari logam, (18) industri furnitur dari kayu yang mencakup usaha pembuatan furnitur dari kayu untuk rumah tangga dan kantor, (19) industri furnitur dari rotan dan ataubambu, (20) industri furnitur dari logam, (20) industri furnitur yang mencakup pembuatan furniture yang bahan utamanya bukan kayu, rotan, bamboo, logam, plastik dan bukan barang imitasi, (21) industri permata, (22) industri barang perhiasan berharga untuk keperluan pribadi dari logam mulia, (23) ndustri Barang Perhiasan Berharga Bukan untuk Keperluan Pribadi dari Logam Mulia yang mencakup usaha pembuatan keperluan pribadi, seperti: peralatan makan dan minum, barang hiasan rumah tangga, piala, medali dan noveltis, termasuk bagian dan perlengkapannya, (24) industri barang perhiasan bukan untuk keperluan pribadi dari bukan logam mulia, (25) industri alat-alat musik tradisional, (26) industri alatalat musik non tradisional, (27) industri mainan, (28) industri kerajinan yang tidak diklasifikasikan di tempat lain yang mencakup usaha pembuatan barang-barang kerajinan dari bahan tumbuh-tumbuhan dan hewan, (29) perdagangan besar barang-barang keperluan rumah tangga, (30) perdagangan besar berbagai barangbarang dan perlengkapan rumah tangga lainnya, (31) perdagangan eceran barang perhiasan yang mencakup usaha perdagangan eceran khusus barang perhiasan, (32) perdagangan eceran jam yang mencakup usaha perdagangan eceran khusus berbagai jam, (33) perdagangan eceran furnitur yang mencakup usaha perdagangan eceran khusus furniture, (34) perdagangan eceran barang pecah belah dan perlengkapan dapur dari batu atau tanah liat, (35) perdagangan eceran barang pecah belah dan perlengkapan dapurdari kayu, bamboo atau rotan, (36) perdaganganeceran barang kerajinan dari keramik, (37) perdagangan eceran mainan anak-anak, (38) perdagangan eceran lukisan, (39) perdagangan eceran barang-barang kerajinan, mainan anak-anak, dan lukisan lainnya, (40) perdagangan eceran kaki lima barang kerajinan, dan (41) perdagangan eceran kaki lima lukisan. Kelompok ini mencakup usaha perdagangan.

5. Desain: kegiatan kreatif yang terkait dengan kreasi desain grafis, desain interior, desain produk, desain industri, konsultasi identitas perusahaan dan jasa riset pemasaran serta produksi kemasan dan jasa pengepakan. Lapangan usaha yang merupakan bagian dari kelompok industri desain yaitu: a) Industri Kemasan dan Kotak dari Kertas dan Karton yang mencakup pembuatan segala macam kemasan dan kotak dari kertas/karton yang digunakan untuk pembungkus/pengepakan, pembuatan kotak untuk rokok dan barang-barang lainnya. b) Jasa Riset Pemasaran 
yang mencakup usaha penelitian potensi pasar, penerimaan produk di pasar, kebiasaan dan tingkah laku konsumen, dalam kaitannya dengan promosi penjualan dan pengembangan produk baru. c) Jasa Pengepakan yang mencakup usaha jasa pengepakan atas dasar balas jasa (Fee) atau kontrak serta kegiatanpengalengan, pembotolan, pelabelan, pembungkusan kado dan sejenisnya. d) Jasa perusahaan lainnya yang mencakup jasa stenografi, pelelangan, penterjemahan, dan lainnya

6. Fesyen (Fashion): kegiatan kreatif yang terkait dengan kreasi desain pakaian, desain alas kaki, dan desain aksesoris mode lainnya, produksi pakaian mode dan aksesorosnya, konsultasi lini produk berikut distribusi produk fesyen.Lapangan usaha yang merupakan bagian dari kelompok industri fesyen yaitu: a) Industri pakaian jadi Rajutan. b) Industri Rajutan Kaos Kaki. c) Industri Barang Jadi Rajutan Lainnya. d) Industri Rajutan Jadi dari Tekstil dan Perlengkapannya. e) Industri Pakaian Jadi (Konveksi) dan perlengkapan dari Kulit yang mencakup usaha pembuatan pakaian jadi dari kulit atau kulit imitasi perlengkapannya. f) Industri pakaian Jadi/Barang Jadi dari Kulit Berbulu dan atau Aksesoris. g) Industri Alas Kaki untuk Keperluan Sehari-hari yang mencakup usaha pembuatan alas kaki, keperluan sehari-hari dari kulit dan kulit buatan, karet, kanfas, dan kayu. h) Industri Sepatu olah raga. i) Industri Sepatu Teknik Lapangan/Keperluan. j) Industri Alas kaki lainnya yang mencakup usaha pembuatan alas kaki dari kulit, kulit buatan, karet, kanfas dan plastik yang belum termasuk golongan manapun. k) Perdagangan Besar Tekstil, Pakaian jadi, dan Kulit yang mencakup usaha perdagangan besar hasil industry tekstil dan pakaian jadi ke luar negeri. l) Perdagangan Besar berbagai barang-barang dan perlengkapan rumah tangga lainnya. $\mathrm{m}$ ) Perdagangan Eceran Tekstil yang mencakup usaha perdagangan eceran khusus macam-macam kain batik terbuat dari serat alam, sintetis, maupun campuran, seperti kain tenun dan kain batik. n) Perdagangan Eceran Pakaian Jadi. o) Perdagangan Eceran sepatu, Sandal dan Alas kaki lainnya. p) Perdagangan Eceran Tekstil, Pakaian Jadi, Alas kaki, dan Barang Keperluan Pribadi Lainnya. q) Perdagangan Ekspor Tekstil, Pakaian Jadi dan Kulit yang mencakup usaha mengekspor hasil industry tekstil dan Pakaian Jadi. r) Perdagangan Ekspor berbagai barang-barang dan perlengkapan rumah tangga lainnya. dan s) Jasa Perorangan yang Tidak Diklasifikasikan di Tempat Lainnya, khususnya untuk jasa desainer fesyen dan model fashion.

7. Video,Film, dan Fotografi: kegiatan kreatif yang terkait dengan kreasi produksi video, film dan jasa fotografi, serta distribusi rekaman video dan film. Termasuk di dalamnya penulisan skrip, dubbing film, sinematografi, sinetron, dan eksibisi atau festival film.Lapangan usaha yang merupakan bagian dari kelompok industry film, video, dan fotografi yaitu:a) Reproduksi Film dan Video. b) Produksi dan disribusi film, serta video oleh Pemerintah. b) Produksi dan distribusi film, serta video oleh swasta. c) Kegiatan Bioskop yang mencakup usaha penyewaan film atau video tape dan penyelenggaraan usaha bioskop yang dikelola baik oleh pemerintah atau swasta. Dan d) Jasa Fotografi yang mencakup usaha jasa pemotretan, baik untuk perorangan atau kepentingan bisnis, termasuk pula pemrosesan dan pencetakan hasil pemotretan tersebut. Pemotretan dari udara (aerial photography), dan jasa pemotretan yang dioperasikan oleh mesin. 
8. Permainan Interaktif (game): kegiatan kreatif yang berkaitan dengan kreasi, produksi, dan distribusi permainan computer dan video yang bersifat hiburan, ketangkasan dan edukasi. Sub-sektor permainan interaktif bukan didominasi sebagai hiburan semata-mata tetapi juga sebagai alat bantu pembelajaran atau edukasi.

9. Musik: kegiatan kreatif yang berkaitan dengan kreasi atau komposisi, pertunjukkan, reproduksi, dan distribusi dari rekaman suara.Lapangan usaha yang merupakan bagian dari kelompok industri music mencakup penerbitan dalam media rekaman yang mencakup usaha perekaman usaha di piringan hitam, pita kaset, compact disk (CD) dan sejenisnya. Reproduksi media rekaman yang mencakup usaha reproduksi (rekaman ulang), audio, dan computer dari master copies, rekaman ulang floppy, hard, dan compact disk.

10. Seni Pertunjukkan (showbiz): kegiatan kreatif yang berkaitan dengan usaha pengembangan konten, produksi pertunjukkan. Misalnya, pertunjukkan wayang, balet, tarian tradisional, tarian kontemporer, drama, music tradisional, music teater, opera, termasuk music etnik, desain dan pembuatan busana pertunjukkan, tata panggung, dan tata pencahayaan.Lapangan usaha yang merupakan bagian dari kelompok industri seni pertunjukkan yaitu: a) Jasa Konvensi, pameran, dan perjalanan insentif. b) Impresariat yang mencakup kegiatan pengurusan dan penyelenggaraan pertunjukan hiburan baik yang berupa mendatangkan, mengirim, maupun mengembalikan serta menentukan tempat, waktu, dan jenis hiburan. Kegiatan usaha jasa impresariat ini meliputi bidang seni dan olah raga. c) Kegiatan drama, music, dan hiburan lainnya oleh pemerintah. d) Kegiatan drama, music, dan hiburan lainnya oleh swasta yang dikelola oleh swasta. e) Jasa Penunjang Hiburan yang mencakup usaha jasa penunjang hiburan, termasuk juga agen penjualan karcis/tiket pertunjukkan seni dan hiburan f) Kegiatan Hiburan lainnya yang mencakup kegiatan dalam menyelenggarakan hiburan kepada masyarakat, oleh pemerintah atau swasta.

11. Penerbitan dan Pencetakan: kegiatan kreatif yang berkaitan dengan penulisan konten dan penerbitan buku, jurnal, Koran, majalah, tabloid, dan konten digital serta kegiatan kantor berita dan pencari berita. Subsektor ini juga mencakup penerbitan perangko, materai, uang kertas, blanko cek, giro, surat andil, obligasi, saham dan surat berharga lainnya, paspor, tiket pesawat terbang, dan terbitan khusus lainnya. Juga mencakup penerbitan foto-foto, gravir (engraving) dan kartu pos, formulir, poster, reproduksi, percetakan lukisan, dan barang cetakan lainnya, termasuk rekaman mikro film.Lapangan usaha yang merupakan bagian dari kelompok industri penerbitan dan percetakan yaitu: a) Penerbitan buku, buku pelajaran, atlas/peta, brosur, pamlet, buku music, dan publikasi lainnya. b) Penerbitan surat kabar, jurnal, tabloid, majalah, penerbitan surat kabar, jurnal, tabloid, majalah umum dan teknis, komik dan sebagainya c) Industri penerbitan khusus yang mencakup industri penerbitan perangko, materai, uang kertas, blanko cek, giro, surat andil, obligasi surat saham, surat berharga lainnya d) Industri penerbitan lainnya yang mencakup usaha penerbitan foto-foto, gravir, (engraving) dan kartu pos, formulir, poster, reproduksi, percetakan lukisan, dan barang cetakan lainnya e) Industri percetakan yang mencakup kegiatan pelayanan jasa percetakan surat kabar, majalah, jurnal, buku, pamplet, peta atau atlas, poster dan lainnya f) 
Industri jasa penunjang percetakan yang mencakup usaha penjilidan buku. Produksi composed type, plates, atau cylinders, penjilidan buku. Produksi batu lithographic untuk digunakan dalam kegiatan percetakan di unit lain. g) Perdagangan eceran hasil percetakan, penerbitan, dan perangkat lunak (software) yang mencakup usaha perdagangan eceran khusus hasil percetakan, penerbitan, dan perangkat lunak. h) Kegiatan kantor berita oleh pemerintah yang mencakup kegiatan pemerintah dalam usaha mencari, mengumpulkan, mengolah, dan sekaligus mempublikasikan berita melalui media cetak elektronik. J) Pencari berita (Free Lance) yang mencakup usaha mencari berita yang dilakukan oleh perorangan sebagai bahan informasi.

12. Layanan komputer dan perangkat lunak (software): kegiatan kreatif yang berkaitan dengan pengembangan teknologi informasi, termasuk layanan jasa computer, pengolahan data, pengembangan database, pengembangan perangkat lunak, integrasi system, desain dan analisis system, desain arsitektur perangkat lunak, desain prasarana perangkat lunak dan perangkat keras, serta desain portal termasuk perawatannya.Lapangan usaha yang merupakan bagian dari kelompok industri kelompok layanan computer dan perangkat lunak yaitu: a) Jasa portal yang mencakup usaha jasa pelayanan yang menyediakan akses ke gerbang utama dari pusat enterprise knowledge. b) Jasa multimedia lainnya. c) Jasa konsultasi piranti keras (hardware consulting) yang mencakup usaha jasa konsultasi tentang tipe dan konfigurasi dari piranti keras computer dengan atau tanpa dikaitkan dengan aplikasi piranti. d) Jasa konsultasi piranti lunak yang mencakup usaha jasa konsultasi yang berkaitan dengan analisis, design, dan pemrograman dari system yang siap pakai. e) Pengolahan data yang mencakup jasa untuk pengolahan dan tabulasi semua jenis data. f) Jasa kegiatan data base yang mencakup usaha jasa pelayanan yang berkaitan dengan pengembangan data base, penyimpanan data, dan penyediaan data base dari berbagai jenis data (seperti: data keuangan, statistic, ekonomi atau teknis). g) Perawatan dan reparasi mesin-mesin kantor, akuntansi, dan computer. h) Kegiatan lain yang berkaitan dengan computer. Beberapa kegiatan kunci yang termasuk dalam kelompok ini antara lain adalah pengembangan manajemen system informasi, solusi basis data, system informasi geografis, pengembangan jaringan computer, piranti lunak komputasi, desain aplikasi web, pengembangan multimedia, keamanan jaringan informasi, dan animasi

13. Televisi \& Radio (broadcasting): kegiatan kreatif yang berkaitan dengan usaha kreasi, produksi dan pengemasan acara televisi (seperti games, kuis, reality show, infotaiment, dan lainnya), penyiaran, dan transmisi konten acara telavisi dan radio, termasuk kegiatan station relay (pemancar) siaran radio dan televisi.Lapangan usaha yang merupakan bagian dari kelompok industritelevisi dan radio yaitu: a) Telekomunikasi khusus untuk penyiaran yang mencakup usaha penyelenggaraan telekomunikasi yang khusus digunakan untuk keperluan penyiaran. b) Kegiatan radio dan televisi oleh pemerintah yang mencakup kegiatan pemerintah dalam usaha penyelenggaraan siaran radio dan televisi, termasuk juga station relay (pemancar kembali) siaran radio dan televisi. c) Kegiatan radio dan televisi oleh swasta yang mencakup kegiatan dalam usaha penyelenggaraan siaran radio dan televisi yang dikelola oleh swasta. 
14. Riset dan Pengembangan (R\&D): kegiatan kreatif yang berkaitan dengan usaha inovatif yang menawarkan penemuan ilmu dan teknologi, serta mengambil manfaat terapan dari ilmu dan teknologi tersebut guna perbaikan produk dan kreasi produk baru, proses baru, material baru, alat baru, metode baru, dan teknologi baru yang dapat memenuhi kebutuhan pasar. Termasuk yang berkaitan dengan humaniora, seperti penelitian dan pengembangan bahasa, sastra, dan seni serta jasa konsultasi bisnis dan manajemen.Kegiatan utama kelompok industri riset dan pengembangan termasuk: a) Usaha penelitian dan pengembangan yang dilakukan secara sistematis diselenggarakan oleh swasta berkaitan dengan teknologi dan rekayasa. b) Penelitian dan Pengembangan ilmu pengetahuan sosial yang mencakup usaha penelitian dan pegembangan yang dilakukan secara sistematis, diselenggarakan oleh swasta, berkaitan dengan ilmu social. c) Penelitian dan pengembangan humaniora yang mencakup usaha penelitian dan pengembangan yang dilakukan secara teratur yang diselenggarakan oleh swasta berkaitan dengan humaniora. d) Jasa Konsultasi bisnis dan manajemen yang mencakup usaha pemberian saran dan bantuan operasional pada dunia bisnis.Penggerak kelompok ini adalah pemerintah yang merilis kebijakan nasional ilmu, pengetahuan, dan teknologi. Kebijakan Strategis Pembangunan Nasional Iptek berfokus pada pembangunan ketahanan pangan, penciptaan dan pemanfaatan sumber energy baru dan terbarukan, pengembangan teknologi dan manajemen transportasi, teknologi informasi dan komunikasi, teknologi pertahanan dan teknologi kesehatan dan obat-obatan.

14 unsur ekonomi kreatif sebagaimana yang telah disusun oleh Departemen Perdagangan di atas, sangat memberikan kesempatan dan peluang yang besar bagi perempuan untuk mengembangkan diri melalui kegiatan-kegiatan ekonomi kreatif sehingga dapat meningkatkan kulaitas hidup perempuan dan sekaligus meningkatkan ekonomi keluarga.

\section{PENUTUP}

1. Pemberdayaan perempuanadalah upaya memberikan kesadaran tentang potensi dalam diri perempuan yang dapat berdaya guna dan memberikan keuntungan bagi dirinya maupun orang lain, memberikan motivasi agar tumbuh semangat untuk mengaktifkan potensi yang dimiliki, dan mengembangkannya melalui berbagai pendidikan dan pelatihan, sehingga diperoleh pengetahuan dan keterampilan serta diaplikasikan dalam kegiatan kongkrit yang menguntungkan.

2. Unsur-unsur pemberdayaan perempuan yaitu Welfare (Kesejahteraan), Acces (Akses), Consientisation (konsientisasi), Participation (partisipasi). DanEquality of Control (Kesetaraan Dalam Kekuasaan)

3. Metode pemberdayaan perempuan adalah membongkar mitos kaum, memberi beragam keterampilan, memberikan kesempatan seluas-luasnya bagi perempuan untuk maju dan meningkatkandalam berbagai sektor pekerjaan, baik bidang pendidikan, kesehatan, ekonomi, sosial, politik, hankam, dan budaya.

4. 14 subsektor Ekonomi Kreatif yaitu Periklanan (advertising), Arsitektur, Pasar Barang Seni, Lapangan usaha yang merupakan bagian dari kelompok industri Pasar Seni dan barang antik, Desain, Fesyen (Fashion), Video,Film, dan Fotografi, Permainan Interaktif (game), Musik, Seni Pertunjukkan (showbiz), Penerbitan dan 
Pencetakan, Layanan komputer dan perangkat lunak (software), Televisi \& Radio (broadcasting), dan Riset dan Pengembangan (R\&D).

\section{DAFTARPUSTAKA}

Dania Eka Putri dan Dwi Rizki Wijayanti. 2013. Perkembangan Ekonomi Kreatif Dalam Arus Perkembangan Ekonomi Modern. Fakultas Pendidikan dan Ekonomi UPI Bandung. Skripsi

Edi Suharto, 2003. Pembangunan Kebijakan dan Kesejahteraan Sosial. Bandung: Mizan

Hastuti dan Dyah Respati. Model Pemberdayaan Perempuan Miskin Berbasis Pemanfaatan Sumber Daya Perdesaan Upaya Pengentasan Kemiskinan Di Pedesaan. Studi di LerengMerapi Daerah Istimewa Yoyakarta. Naskah Jurnal Fakultas Ilmu Sosial Ekonomi UNY Yogyakarta

Herie Saksono, 2012. Ekonomi Kreatif : Talenta Baru Pemicu Daya Saing Daerah. Puslitbang Pemerintahan Umum dan Kependudukan Balitbang (BPP) Kementerian Dalam Negeri.

Ismah Salman, 2005. Keluarga Sakinah Dalam Aisyiyah, Jakarta: PSAP Muhammadiyah.

Merla Liana Herawati, 2014. Pemberdayaan Ekonomi Masyarakat Melalui Kerajinan Tempurung Kelapa: Studi Di Dusun Santan Guwosari Pajangan Bantul. Fakkultas Dakwah Dan Komunikasi. UIN Sunan Kalijaga Yogyakarta. (Skripsi).

Retni Endah Supeni dan Maheni Ika Sari, 2011. Upaya Pemberdayaan Ekonomi Perempuan Melalui Pengembangan Manajemen Usaha KecilStudi diskriptif pada Kegiatan Usaha Kecil Ibu-ibu Desa Wirolegi Kabupaten Jember, Dampingan Pusat Studi Wanita UM Jember.Seminar Nasional Ilmu Ekonomi Terapan Fakultas Ekonomi UNIMUS. Universitas Mubammadiyah Jembe

Sukmika Mardalena, 2012. Dominasi Produk Cina di Indonesia. Fakultas Ilmu Sosial dan Ilmu Politik, ProdiHubungan Internasional, Universitas Riau. (Makalah)

UNCTAD, 2008. Summary Creative Economic Report.USA: United Nations

Zakiyah, Pemberdayaan Perempuan oleh Lajnah Wanita, Jurnal Pengkajian Masalah Sosial Keagamaan, XVII, Januari-Juni 2010

http://www.mediapustaka.com/2014/11/makalah-pengembangan-ekonomi-kreatif.html 